\title{
Bacterial Antagonist Mediated Protein Molecules
}

\author{
Lucía Urbizu'1,2, Mónica Sparo ${ }^{1,3}$ and Sergio Sánchez Bruni ${ }^{1,2 *}$
}

${ }^{1}$ Laboratory of Pharmacology, Faculty of Veterinary Medicine, Universidad Nacional del Centro de la Pcia de Buenos Aires-Tandil-Argentina, Tandil Veterinary Research Center (CIVETAN)-CONICET, Argentina

${ }^{2}$ Consejo Nacional de Investigaciones Científicas y Técnicas (CONICET), Argentina

${ }^{3}$ Clinical Department, School of Medicine, Universidad Nacional del Centro de la Pcia de Buenos Aires-Tandil, Argentina

\begin{abstract}
Bacterial antagonism mediated by ribosomally synthesised peptides has gained considerable attention in recent years because of its potential applications in the control of undesirable microbiota. These peptides, generally referred to as bacteriocins, are defined as a heterogeneous group of ribosomally synthesised, proteinaceous substances (with or without further modifications) extracellularly secreted by many Gram-positive and some Gram-negative bacteria. Their mode of activity is primarily bactericidal and directed against closely related strains and species. These peptides are nearly all cationic and very often amphyphilic, which is reflected in the fact that many of these peptides kill their target cells by accumulation in the membrane causing increasing permeability and loss of barrier functions. Bacteriocins have been explored primarily as natural food preservatives, but there is much interest in exploring the application of these therapeutic peptides as antimicrobial agents since many of them exhibit antimicrobial activity against various important human pathogens. The suitability of bacteriocins such as pharmaceuticals is explored through measures of cytotoxicity, effects on the natural microbiota, and in vivo efficacy in mouse models. Bacteriocins are promising therapeutic agents.
\end{abstract}

Keywords: Bacteria; Protein; Veterinary; Human medicine

\section{Introduction}

Antimicrobial resistance of bacteria is a pivotal health concern worldwide in Human, as well as Veterinary Medicine. Undoubtedly, the excessive and often empiric antimicrobials for the treatment of different clinical situations has led to changes in the bacterial ecology, leading to fatal consequences for public health. Scientists say that the community-acquired sepsis should be distinguished from nosocomial sepsis (nosocomial). As it is known, their differences are the main sources of infection, the predominant bacteria and the sensitivity to the antimicrobial. The process is well known and studied of bacterial resistance becomes larger in the hospital environment, where there have been very aggressive microbes that spread easily from patient to patient. The bacteria acquire the ability to resist the action of antibiotics through several mechanisms such as genetic variability, the modification of the permeability of the inner membrane, extraction of the compound and enzyme inhibition, as well as modification of the target ribosomal or altering the composition and content of glycoproteins of the bacterial wall [1]. This resistance is transferred between organisms of the same genus (horizontal transmission) and between organisms of different genus (vertical transmission). Even more, the fact that there is limited data on antibiotic susceptibility and resistance surveillance in all countries (in either, Veterinary and Human Medicine), must be added. Many foods of animal origin are often reservoirs of bacteria carrying resistance genes. These bacteria into the gastrointestinal tract may transfer their resistance genes to the intestinal microbiota being the consequence the follow resistance sequence transfer animal-animal, animal- human, human-human [2].

\section{Antimicrobial Peptides}

The scientific work on bacterial antagonism-mediated by protein molecules was sourced on the 80 's being now a significant area of research, whose results are reflected in the description of a large family of antimicrobial substances, known as antimicrobial peptides (AMPs). These peptides are produced by many cell types in a variety of life forms found in protozoa, prokaryotes, plants and animals [3-17]. Some of them are produced constitutively and others are synthesized in response to microbial attack [4-25]. Probably one of the attractions has been considered that such molecules represent an ancestral defense mechanism still not explored [20]. It will constitute an alternative to today's predicament posed by the emergence of resistance to antibiotics [19-23]. Among the identified proteins and peptides is a great diversity of primary structures, but in most cases are cationic molecules ribosomal synthesis-mediated [9]. These molecules, often amphiphilic [24], direct its action to the bacterial membrane, interacting with the negatively charged structures leading to its permeabilization [7-25]. Nowadays, its known that not only AMPs' produce permeabilization of bacterial membranes, but also have other role such as inhibition of protein synthesis or DNA, the antitumor activity, and stimulation of cell proliferation or angiogenesis [25]. Target organisms of antimicrobial peptides are very diverse (enveloped viruses, bacteria, fungi, trypanosomes, protozoa, parasites and cancer cells) but they all have in common the possession of a negatively charged surface membrane, low concentration of cholesterol and high transmembrane electric potential [26,27].

There is no correlation between the activity of AMPs and its isoelectric point, molecular weight or length. However, it has been shown to possess residues Lys and Arg helps peptides to reach the bacterial membranes, although the mechanism involved in permeabilization. Two factors that determine the permeability activity of antimicrobial peptides are amphipathic and hydrophobicity [19]. It has recently been seen some AMPs insert their propellers obliquely to promote permeabilization membrane [28].

\section{AMPs Produced by Bacteria}

Antimicrobial peptides produced by bacteria are also called bacteriocins, and defined as "a heterogeneous group of ribosomal synthetic peptides with or without further modifications, which are secreted extracellularly and have a bactericidal mechanism of action

*Corresponding author: Sergio F. Sánchez Bruni, Laboratory of Pharmacology Faculty of Veterinary Medicine, Universidad Nacional del Centro de la Pcia de Buenos Aires-Tandil (7000), Argentina, E-mail: ssanchez@vet.unicen.edu.ar

Received March 07, 2013; Accepted March 20, 2013; Published March 23, 2013

Citation: Urbizu L, Sparo M, Sánchez Bruni S (2013) Bacterial Antagonist Mediated Protein Molecules. Clin Exp Pharmacol 3: 123. doi:10.4172/2161-1459.1000123

Copyright: @ 2013 Urbizu L, et al. This is an open-access article distributed under the terms of the Creative Commons Attribution License, which permits unrestricted use, distribution, and reproduction in any medium, provided the original author and source are credited. 
against related strains" $[29,30-32]$. However, that some bacteriocins in Gram-positive have a broader spectrum $[33,34]$ and in some cases may extend beyond the borders of bacteria and include protozoa, yeasts, fungi, and virus [35]. Bacteriocin differ from eukaryotes antimicrobial peptides in the high self-toxicity showing the second, as is the case of defensins produced by human neutrophils that are cytotoxic at high concentrations to the producing cell itself [36]. AMPs from bacteria differ basically from traditional antibiotics in: a) molecular structure, b) chemicals nature, c) mode and range of action, and d) absence of toxicity and induced resistance mechanisms [37]. Like bacteriophages, the bacteriocins can specifically target a particular subset of bacterial strains or species. However, unlike viruses, some bacteriocins were found to be safe for human consumption by the Food and Drug Administration [38].

Its importance lies in the fact that these inhibitors have been described in virtually all lineages Domain Bacteria, and frequently the production of various types of bacteriocins from strains of the same species [30-41]. The bacteriocin family may be divided into two Gram-negative and Gram-positive's bacteria main groups $[42,43]$. Bacteriocins have primarily been characterized in Gramnegative bacteria, in which is described the colicins produced by Escherichia coli [44-46], and the microcin generated by members of the Enterobacteriaceae family $[47,48]$.

\section{AMPs Obtained from Gram-Positive Bacteria}

Bacteriocins of Gram- positive are abundant and more diverse than those described at the present for Gram-negatives [29-31]. The Grampositive bacteriocins resemble many of the antimicrobial peptides produced by eukaryotes. They are generally cationic, amphiphilic, membrane permeabilizing peptides ranged in size from 2 to $6 \mathrm{kDa}$ [43]. They also differ from bacteriocins of Gram-negative bacteria in two elementary ways according [49]. Firstly, the bacteriocins produced by Gram-positive bacteria are not necessarily lethal to the producing cell. This pivotal difference is because the transport mechanisms Gram-positive bacteria encode the release of the bacteriocin-toxin. Typically, their biosynthesis is self-regulated with specifically dedicated transport mechanisms facilitating release, although some employ the Sec-dependent export pathway [50-52]. Secondly, the Grampositive bacteria have evolved bacteriocin-specific regulation, whereas bacteriocins of Gram-negative bacteria rely solely on host regulatory networks [53].

The last twenty years of research has focused primarily on the study of bacteriocins produced by Lactic Acid Bacteria (LAB) on feasibility of using them as natural food preservatives in order to increase the lifetime and improve the hygienic quality of them. According to the structural and biological characteristics of LAB's bacteriocins, [54] established four classes of bacteriocins, in which the first three are still recognized today. The discovery and characterization of new bacteriocins has become necessary to amend this classification, especially for class II [37-58]. Table 1 shows the classification of bacteriocins described by Diep et al. [32] and Cotter et al. [58] as follows: Class I: named lantibiotics, because they are post-translationally modified. These substances contain amino acids such as lanthionine and $\beta$-methyl lanthionine, and many dehydrated amino acids $[59,60]$. Based on the structural characteristics and mode of action, lantibiotics have been subdivided into two subgroups: A and B. Type A lantibiotics inhibit depolarization-sensitive cells of the cytoplasmic membrane $[61,62]$ these are larger than type B lantibiotics and their size varies between 21 and 38 amino acids. The best bacteriocin studied of Gram-positive bacteria [63]. Nisin has a dual mode of action: (1) They bind to lipid II, the main transporter of peptidoglycan subunits from the cytoplasm to the cell wall, and therefore prevent correct cell wall synthesis, leading

\begin{tabular}{|c|c|c|c|}
\hline CLASS & SUBCLASS & EXAMPLES & REFERENCE \\
\hline $\begin{array}{l}\text { Class I } \\
\text { Lantibiotics } \\
<5 \mathrm{KDa}\end{array}$ & $\begin{array}{l}\text { la: Cationic } \\
\text { linear } \\
\text { peptides. } \\
\text { Globular peptides } \\
\text { without } \\
\text { charge or net charge negative. }\end{array}$ & $\begin{array}{l}\text { Nisin } \\
\text { Epidermin } \\
\text { Lacticin } 3147 \\
\text { Mersacidin }\end{array}$ & $\begin{array}{l}{[154]} \\
{[123]} \\
{[156]} \\
{[95]}\end{array}$ \\
\hline $\begin{array}{l}\text { Class II } \\
\text { Bacteriocins } \\
\text { heat-stable unmodified } \\
<10 \mathrm{kDa}\end{array}$ & $\begin{array}{l}\text { Ila: } \\
\text { Anti-Listeria bacteriocins similar to pediocin. } \\
\text { IIb: } \\
\text { Heterodimeric } \\
\text { Bacteriocins. } \\
\text { IIc: } \\
\text { Sec-dependent } \\
\text { Bacteriocins. } \\
\text { Ild: } \\
\text { Bacteriocins without } \\
\text { leader peptide. } \\
\text { Ile: } \\
\text { Cyclical } \\
\text { Bacteriocins. } \\
\text { IIf: Nonclustered } \\
\text { Bacteriocins. }\end{array}$ & $\begin{array}{l}\text { Pediocin PA-1 } \\
\text { Enterocin A } \\
\text { Lactacin F } \\
\text { Lactococcin G } \\
\text { Bacteriocin } 31 \\
\text { Enterocin P } \\
\text { EJ97 } \\
\text { Enterocin L50 } \\
\text { AS-48 } \\
\text { Circularin A } \\
\text { Gassericin A } \\
\text { Lactococcin A } \\
\text { Enterocin B }\end{array}$ & $\begin{array}{l}{[11]} \\
{[52]} \\
{[37,41,76]} \\
{[11]}\end{array}$ \\
\hline $\begin{array}{l}\text { Class III } \\
\text { Large heat-labile proteins } \\
\text { (Bacteriolisins) }{ }^{*}>30 \mathrm{Kda}\end{array}$ & & $\begin{array}{l}\text { Helveticin J } \\
\text { Enterolisin A }\end{array}$ & {$[54]$} \\
\hline
\end{tabular}

Table 1: Classification of bacteriocins based on classifications proposed by Diep et al. $[23,32,53]$ and Cotter et al. [58,68]. Class IV (non-protein motifs bacteriocins) is not included because it has not demonstrated the existence of members of this class. * It is suggested that this class is not considered as bacteriocins. 
to cell death, and (2) they employ lipid II as a docking molecule to initiate a process of membrane insertion and pore formation that leads to rapid cell death [64]. The type B lantibiotics are more globular secondary structure and do not exceed the 19 amino acids long. The type B lantibiotics works through enzyme inhibition. An example is the mersacidin, which interferes with cell wall biosynthesis [65]. The other well studied lantibiotic, Lacticin 3147, consists in two lantibiotic peptides that synergistically display antimicrobial activity [66,67]. It was shown that the dual activities could be distributed across two peptides: While one resembles type B lantibiotic mersacidin, which depolarizes the membrane, the other one is more similar to the type A lantibiotic class pore formers [68]. Bacteriocins of LAB class II are also small, ranging in size from 30 to 60 amino acids, are heat stable and contain no lanthionine in peptides [69]. These are further classified into 6 subgroups: Class IIa: are potent inhibitors of Listeria species, showing activity at low nanomolar concentrations. These bacteriocins are heat-stable and not post-translationally modified beyond the proteolytic removal of a leader peptide and the formation of a conserved $\mathrm{N}$-terminal disulfide bridge (although some members contain an additional $\mathrm{C}$-terminal disulfide bridge). The $\mathrm{N}$-terminal region contains the alternate YGNGL sequence have been classified in class IIa. Briefly, class IIa bacteriocins kill susceptible bacteria by forming pores in their membranes. Initially, the bacteriocins are attracted by electrostatic interaction and then inserted in the membrane forming pores. This mechanism of action is dependent on a complex protein MannosePhosphotransferase (MPT) found in the membranes of susceptible organisms, but the exact nature [70]. Class IIb bacteriocins, act forming pores in the membranes of their target cells and are composed of two proteins that function complementarily. The subgroup IIc consists of bacteriocins that are sec-dependent. The subgroup IId is not leader peptide Bacteriocins and transport systems used are typical of the bacteriocin (specific). The subset IIe are Cyclic Bacteriocins and finally the subgroup consisting of Bacteriocins IIf not clustered in the above classifications. Class III bacteriocins are large proteins and heat sensitive. The proposed additional class of bacteriocins (IV) is characterized by incorporating groups such as carbohydrates or lipids in the molecule to be active. Little is known about the structure and function of this class, some examples include leuconocin S [71] and lactocin 27 [72].

Several reports described the Enterococcus' production of bacteriocins, also named enterocins. Most studies have been conducted on the species E. faecalis and E. faecium [73-75]. The best enterocin characterized from the genetics and biochemistry viewpoint is AS-48, a characteristic YGNGV amino acid sequence, although variants with

which presents the most unusual feature of being a circular protein, having a broad spectrum of action. For this reason, Kemperman et al. [76] and Maqueda et al. [77], proposed to include the enterocin AS48 in a new class (class V) of circular bacteriocins. LAB's bacteriocins enterococci have certain general characteristics [78,79]: a) can be readily isolated from fermented foods, are stable to the action of heat (up to $70-100^{\circ} \mathrm{C} 5 \mathrm{~min}$ ), b) retain activity in a wide $\mathrm{pH}$ range ( $\mathrm{pH} 4-8$ ), c) have important biological activity on Listeria spp. and bactericidal activity (Listeria, Clostridium, Staphylococcus). The most notorius enterocins characterized are shown in Table 2. Other enterocins have been discovered and characterized at the present, such as APCECT7121 isolated from a strain of E. faecalis recovered from corn silage [80]. This antimicrobial peptide have a broad spectrum of inhibitory activity against Gram-positive bacteria such as Listeria spp., other species of Enterococci, S. aureus, Streptococcus spp., Bacillus spp. and Clostridium spp. and some Gram-negative like E. coli and Shigella spp. [81,82]. It has also been reported in vivo antiparasitic activity [83], immunomodulation properties [84,85], antitumor action [86] and food biopreserver [80]. AP-CECT7121 is stable at a $\mathrm{pH}$ range of 4.0-8.0. This enterocin belong to in the group II of the classification of [87]. When the bacteriocin AP-CECT7121 was studied against Gram-positive and Gram-negative a broader spectrum of inhibition was observed compared with other bacteriocins $[31,88,89]$. The fact that the enterocin maintain inhibitory activity at different $\mathrm{pH}$ from 4 to 8 , gives this potential use in fermented food which is subject to variations in $\mathrm{pH}$ during processing and maturation [90]. The action mechanism of this peptide would involve the formation of pores in the cytoplasmic membrane and the output of cellular material, as observed with enterocin 100 and AS-48 [91,92]. Other studies conducted "in vitro" showed the effectiveness of this peptide against a broad range of bacteria resistant Gram-positive aerobic and anaerobic conditions many of which were associated with multidrug resistance to conventional antibiotics [82]. Also the AP-CECT7121 enterocin has shown activity in vitro on common bacteria that produce mastitis in cattle [81]. Studies performed with the plasmid CECT7121 enterocin indicate that the plasmid contains genes encoding both its production and immunity. The broad spectrum of inhibitory activity, its stability in a wide range of $\mathrm{pH}$ and temperature (heat resistant, inactivation occurs at 15 minutes at $121^{\circ} \mathrm{C}$ ) make the AP-CECT7121 enterocin is a molecule to be studied as a preservative food, as well as therapy of common infectious diseases refractory produced in human and veterinary medicine.

\section{Applications of Bacteriocins in Food}

A wide range of bacteriocins produced by BAL have been intensively

\begin{tabular}{|c|c|c|c|}
\hline Microorganism & Bacteriocin & Type & Mass Da)(aminoacids) \\
\hline E. faecalis & Cytolysin & Class I two-peptide & 3,458 (38), 2,032 (21) \\
\hline E. faecium & Enterocin A & Class Ila Pediocin-like & 4,829 (47) \\
\hline E. faecium & Enterocin P & Class Ila Pediocin-like & 4,493 (44) \\
\hline E. faecium & Bac 32 & Class Ila Pediocin-like & $7,998(70)$ \\
\hline E. faecium & Bacteriocin GM-1 & Class Ila Pediocin-like & 4,630 (44) \\
\hline E. faecalis & Bac 31 & Class Ila Pediocin-like & (43) \\
\hline E. mundtii & Mundticin ATO6, Mundticin KS & Class Ila Pediocin-like & 4,287 (43) \\
\hline E. faecalis & Enterocin SE-K4 & Class Ila pediocin-like & $5,356.2(43)$ \\
\hline E. faecium & Bacteriocin T8 & Class Ila pediocin-like & $5,090(44)$ \\
\hline E. faecium & Enterocin B & Class Ila & $5,479(53)$ \\
\hline E. faecalis & Enterocin 1071A, enterocin 1071B & Class Ilb two-peptide & 4,285 (39), 3,897 (35) \\
\hline E. faecalis & MR10A MR10B & Class Ilc, leaderless & 5,202 (44), 5,208 (43) \\
\hline E. faecium & Enterocin L50; L50A, L50B & Class IIc, leaderless & 5,190 (44), 5,178 (43) \\
\hline E. faecium & Enterocin $Q$ & Class Ilc, leaderless & 3,980 (34) \\
\hline E. faecalis & Enterocin EJ97 & Class Ilc, leaderless & $5,328(44)$ \\
\hline E. faecium & Enterocin RJ-11 & Class Ilc, leaderless & 5,049 (44) \\
\hline E. faecalis & AS-48 & Class Ild circular bacteriocin & $7,166(70)$ \\
\hline
\end{tabular}

Table 2: Classification of enterocins described from Nes et al., 2007. 
investigated enabling detailed chemical characterization [93]. Because BAL has been used for centuries to fermented foods, they are generally regarded as safe by the FDA (Food and Drug Administration). Nisin was the first bacteriocin isolated and approved in 1988 by FDA, for using in foods specifically to prevent the outbreak of Clostridium botulinum spores in cheese spread in England [94]. The use of nisin has a long history and is currently used as a safe food preservative in about 48 different countries [93]. The attention of bacteriocin researchers were focused on the bacterium Listeria monocytogenes, the causative agent of listeriosis, because the frequency of outbreaks of infection combined with increased natural resistance of the causative agent. Furthermore, the study of this bacterium was interesting because of its ability of growing at refrigerated ion temperatures close to that used for traditional food preservation. This led to the isolation of a large number of Class IIa bacteriocins, which are highly active against $L$. monocytogenes [95]. Bacteriocins have also been used in cured meat, milk, cheese and soybean meal [49].

Pediodicin, is a class IIa bacteriocin made by lactic acid producing bacteria. A pediodicin producing strain has also been added to sausages finding a reduction in bacterial numbers approximately 10000 times compared to untreated sausage number [96]. In addition, the active pediodicin was found in the inlays two months after cooling. Another example of a bacteriocin that could be used in the food industry is the piscicolin, a bacteriocin from another lactic acid producing bacteria [96]. The piscicolin has already been patented and will soon be used in meat products and to wash salad greens [96]. The Acidocin LCHV is another antimicrobial peptide produced by Lactobacillus acidophilus n.v. Er 317/ 402 strain Narine, probiotic bacteria widely used as a supplement to dairy milk [97]. A number of other bacterially derived AMPs are also used as food preservatives $[98,99]$. AP-CECT7121 is a peptide with potential application in the food industry, for its broad spectrum of antimicrobial activity, its stability to different temperatures and $\mathrm{pH}$ range [80]. A study in dry sausages was undertaken to evaluate its performance as biopreservative, showing good peptide activity against food pathogens with the advantage of not affecting the growth of Lactobacillus spp. [80].

One concern about the use of bacteriocins for food preservation is the selection of resistant strains. BAL studies have shown the generation of resistant strains of bacteriocin activity after having exposed the sensitive strain at 25 cycles of continuous growth in the presence of the bacteriocin [100]. Treatment with a combination of bacteriocins, such as nisin could theoretically reduce the incidence of resistance [101,102]. An additional concern is whether the resistance to a class of bacteriocin BAL may result in cross-resistance with other kinds of bacteriocin [101]. However, the diverse chemical nature of bacteriocins suggest different modes of action, which leads to believe that cross-resistance is more difficult to obtain, although, it has been reported some crossresistance between different bacteriocins within the class IIa [103]. Interestintingly, at the present there are not described disavantages of using of bacteriocins in food.

\section{In Vivo Utilization of Bacteriocins and Biomedical Applications}

Bacteriocins have been primarily explored as natural food preservatives, but there is much interest in exploring the application of these peptides as therapeutic antimicrobial agents. Several bacteriocins possess antimicrobial activity against several important human pathogens. The use of bacteriocins in vivo has been focused on the introduction of probiotic bacteria in the gastrointestinal tract. Fewer studies have been conducted by administering the purified bacteriocin itself in animals. The use of probiotic strains could be beneficial as a prophylactic, but the use of purified bacteriocins seems to be higher to offset an established infection. This has been demonstrated by administration of PA-1 pediocin Pediococcus acidilactici UL5, a producer of pediocin PA-1, to mice infected with L. monocytogenes [104].

A major concern regarding the use of antibiotics is the effect on the body's microbiota. The presence of commensal bacteria provides a barrier of great value for infection by opportunistic pathogens. Ideally, an antimicrobial agent should have specific activity on pathogenic bacteria with minimal impact on the natural microbiota. PA-1 pediocin has been tested in vitro against human intestinal bacteria such as bifidobacteria and at the concentrations tested, no antagonistic activity was observed. In contrast, in similar studies, lantibiotics such as nisin class I A and nisin Z, showed inhibition against most of the Gram-positive strains tested $[105,106]$.

\section{Relationsip between Administration Route and Efficacy}

In vivo studies in mouse model pediocin PA-1 had no effect on the intestinal microbiota [107] unlike conventional antibiotics such as penicillin and tetracycline [106]. Other studies undertaken in mice infected with L. monocytogenes, reported the use of two different routes of administration of the bacteriocin: intravenous [108,109] and intragastric [104]. Piscicolin 126, RV41 divercin recombinant (DvnRV41) and structural variants of DvnRV41 were administered intravenously to mice immediately before infection with $L$. monocytogenes $[108,109]$. Injection of both bacteriocins was effective in 15 minutes pre-challenge and 30 minutes after challenge. However, administration of 126 piscicolin 24 hours after challenge showed no significant reduction in the count of Listeria. Both of these experiments used only $2 \mathrm{~g}$ of purified bacteriocin. The fact that Listeria is an intracellular pathogen may explain the lack of sensitivity observed after administration of bacteriocin 24 hours after challenge [110]. One concern with the intravenous administration of peptides is the possibility of generate immune response. To corroborate the latter, pediocin $\mathrm{ACH}$ was introduced intraperitoneally in mice and rabbits to determine its antigenic properties, showing no effect on antibody response, appearing to be not immunogenic [111].

The intragastric administration of bacteriocins has also been studied on Class IIa bacteriocins, which are susceptible to common digestive proteases. However, IIa bacteriocins tend to be relatively stable to acidic conditions, and pediocin PA-1 was stable at $\mathrm{pH}$ 2.5 for at least two hours [112]. The stability of bacteriocins in the gastrointestinal tract has been examined by passing purified pediocin PA-1 through an artificial system mimicking the human stomach and small intestine [113]. Pediocin PA-1 activity retained after 90 minutes in artificial gastric conditions, whereas all activity was lost once the sample was in the duodenal compartment. It was suggested that pancreatin in the duodenum was responsible for cleaving the end of PA-1 pediocin, while a combination of pepsin and low $\mathrm{pH}$ may be responsible for the decrease of the activity observed in the gastric chamber [107]. However, intragastric administration of PA-1 pediocin has proven effective to reduce the load L. monocytogenes in a mouse model [104]. Moreover, different pharmacothecnic strategies for protecting bacteriocins have been assayed. The peptide encapsulation may preserve the power in the bacteriocin gastrointestinal tract, although this has not been reported for IIa bacteriocins. However, the nisin's liposome encapsulation has shown some success in other studies $[114,115]$. Intragastric administration of PA-1 pediocin in mice 
infected with $L$. monocytogenes has been examined by Dabour et al. [104], were $250 \mu \mathrm{g}$ of treatment with PA-1 pediocin daily for three consecutive days resulted in a $2 \log$ reduction in fecal Listeria account. L. monocytogenes in general comes through the epithelium barrier, after entering the small intestine and then extending the system of liver, spleen and central nervous systems [110]. This bacteriocin treatment was found to decrease the amount of L. monocytogenes reaching the liver and spleen [104].

\section{Current and Potential Applications in Veterinary and Human Medicine}

The lack of toxicity of bacteriocins to humans and animals and the activity to pathogenic bacteria became these peptides in potential therapeutic alternatives.

Treatment of methicillin-resistant Staphylococcus aureus (MRSA) and vancomycin-resistant Enterococcus faecalis (VRE) in pre-clinical trials

It has been demonstrated in pre-clinical trials that Mersacidin, a lantibiotic produced by Bacillus sp. strain HIL Y-85 54728 [116], inhibits in vivo the growth of MRSA strains in murine model [117]. The mechanism of action of mersacidin is through the inhibition of the cell wall synthesis, being its efficacy similar to the antibiotic vancomycin $[118,119]$. Other peptide, Lacticin 3147 , which is a bacteriocin isolated from Lactococcus lactis subsp. Lactis also inhibits in vitro the growth of S. aureus, MRSA and VRE [120]. Other portential peptide named APCECT7121 (bacteriocin isolated from Enterococcus faecalis CECT7121) [80] has shown in vitro efficacy against some strains of enterococcal and streptococcal, hospitalary and community-acquired methicillinresistant $S$. aureus [82].

\section{Treatment of skin infections}

Mersacidin is also active against Propionibacterium acnes having a potential use in the treatment of acne [121-124]. Epidermin, lantibiotic isolated from Staphylococcus epidermidis is also effective in treating skin infections [123]. This peptide is active against P. acnes and Micrococcus flavus [121,125]. Gallidermin, lantibiotic isolated from Staphylococcus gallinarum, has also proven effectiveness against skin infections [123]. This peptide is also active against $P$. acnes, Staphylococcus simulans and Micrococcus flavus [121,125].

\section{Prevention of tooth decay and gingivitis}

Nisin has been included in mouthwashes as antimicrobial activity against bacteria that produce plaque and gingivitis [126]. Lacticin 3147 inhibits the growth of Streptococcus mutans associated with dental caries [120]. Salivaricin A2 and B, isolated from Streptococcus salivarius inhibit bacteria associated with bad breath [127]. Mutacin 1140 , bacteriocin isolated from Streptococcus mutans is active against bacteria from caries [128].

\section{Infections caused by contaminated biomedical implant} devices

Nisin adsorbed to surfaces silanized, prevent the growth of Listeria monocytogenes [129]. Other study carried out on PVC tracheotomy tubes coated with Nisin, indicated tha Nisin prevent the colonization of S. aureus, S. epidermidis, and Streptococcus faecalis [130].

\section{Upper respiratory tract infections}

Nisin inhibited the growth of $S$. pneumoniae associated with otitis media in in vivo trials [131]. Nisin may also inhibit the growth of $P$. aeruginosa when used in combination with polymyxin $\mathrm{E}$ and clarithromycin [132]. ST4SA peptide, a class II bacteriocin, showed efficacy against Gram-positive bacterial pathogens of the middle ear compared with other antimicrobial agents [133]. Bcn5 bacteriocin showed in vivo efficacy against Mycobacterium tuberculosis in a murine model of experimental infection, but it was less effective than the clinically used antibiotic, rifampicin [134]. Nisin F showed in vivo efficacy against $S$. aureus in the respiratory tract of immunosuppressed rats when administered intranasally [135].

\section{Systemic Infections}

Pediocin PA-1 produced by Pediococcus acidilactici, is active against various strains of L. monocytogenes [136,137]. Furthermore, Pediocin PA-1 has the advantage of not inhibiting other intestinal bacteria when administered intragastrically, compared to Nisin A and Nisin Z [106]. Also, it has been domostrated that Piscicolin126 was active against Listeria monocytogenes in various tissues in murine model [108]. A similar effect has been reported for Abp118, a bacteriocin produced by Lactobacillus salivarius UCC118 and for Divercin V41 [109-138]. Nisin inhibits Clostridium botulinum [139], Clostridium tyrobutyricum [140] and Clostridium difficile [141]. AS-48 bacteriocin produced by Enterococcus faecalis, inhibits the growth of Salmonella choleraesuis [142]. Enterocin 012 isolated from Enterococcus gallinarum 012, is active against Salmonella typhimurium [143]. The peptide APCECT7121 inhibits "in vitro" the growth of Clostridium perfringens and C. difficile [82].

\section{Stomach ulcers}

Interestingly, it has been reported that Nisin, Lacticins A164 and BH5 inhibit in vitro the growth of Helicobacter pylori and therefore would have potential application in treating stomach ulcers [139-144]. However, no in vivo studies have been reported at the present.

\section{Inflammation and allergy}

It has reported that Duramycin B and C, and Cinnamycin are lantibiotics, which act indirectly by inhibiting phospholipase A2, sequestering the substrate phosphatidylethanolamine [145,146] have potential as anti-inflammatory drugs [126].

\section{Treating high blood pressure}

Cinnamycin and Ancovenin are two lantibiotics that inhibit angiotensin converting enzyme [121-147], so they would have potential for treating high blood pressure [148].

\section{Infections of the urogenital tract}

Subtilosin A, originally isolated from wild-type B. subtilis 168 by [149] and recently found in B. amyloliquefaciens [150] is active against Gardnerella vaginalis and offers the advantage of not inhibit Lactobacillus part of the natural microflora in the vagina [150].

\section{Spermicidal activity and potential contraceptive}

Nisin also showed contraceptive activity [151] and protective vaginal animal studies [35]. Subtilosin also showed potent spermicidal activity in vitro studies with human sperm [152] and also in vivo studies in animals [153].

\section{Bovine bacterial mastitis}

Nisin is effective in the treatment of bovine mastitis, being approved by FDA by intramammary administration in dairy cattle $[154,155]$. 
Other bacteriocins, like Lacticin 3147 have shown inhibition against streptococci and staphylococci causing bovine mastitis [156]. LFB112, bacteriocin produced by Bacillus subtilis, also inhibited the growth of $S$. aureus associated with mastitis [157]. Macedocin ST91KM, bacteriocin produced by Streptococcus gallolyticus subsp. macedonicus could also be considered an alternative in treatment of mastitis coil since this peptide inhibits Streptococcus agalactiae, Streptococcus dysgalactiae subsp. dysgalactiae, Streptococcus uberis, Staphylococcus aureus and Staphylococcus epidermidis, including resistant strains methicillin and oxacillin [158-159]. Other peptide named AP-CECT7121 has also shown in vitro efficacy against Staphylococcus aureus, Streptococcus dysgalactiae, S. uberis, S. agalactiae strains isolated from dairy cattle with mastitis [81].

\section{Parasitic infections}

AP-CECT7121, bacteriocin isolated from Enterococcus faecalis CECT7121 showed antiparasitic activity on Toxocara canis through studies in vitro and in vivo mouse model of experimental infection [83160].

\section{AMPS Citoxicity}

Class IIa bacteriocins have been primarily explored as natural food preservatives, but there is much interest in exploring the application of these peptides as therapeutic antimicrobial agents [70]. The suitability of bacteriocins as pharmaceuticals is explored through determinations of cytotoxicity, effects on the natural microbiota, and in vivo efficacy in mouse models.

One advantage of bacteriocins from other antimicrobial treatments is their composition. These peptides are metabolized easily to amino acids, which also involves the disadvantage of being shorter in their antimicrobial activity. In vitro cytotoxicity studies with bacteriocins have been made. The Cytotoxicity of PA-1 pediocin was tested against simian virus 40-transfected Human colon cells and Vero monkey kidney cells [161], showing cytotoxic effects in both cell lines, with a dose of bacteriocin $700 \mathrm{AU} / \mathrm{ml}$ (probably about 10-20 mg / ml) caused a greater reduction $50 \%$ viable cell counts. Lower doses also affected the viable cell count, although this was not so dramatic. However, combinations of carnobacteriocins BM1 and B2 at concentrations 100 times greater than required for antimicrobial activity showed no significant cytotoxic effects on human intestinal cell line Caco-2 [162]. The means of production and purification of bacteriocins should also be considered in toxicity studies. As with all antibiotic therapy, development of resistance to bacteriocins in bacterial pathogens is a critical issue to consider. This topic has been the subject of a recent review of Kaur et al. [163]. Of particular concern is that cross-resistance has been observed for the bacteriocins of different classes. For example, a strain of L. monocytogenes have shown resistance to Nisin, Pediocin PA-1, and S Leuconocin, bacteriocins of three separate classes [164]. On this basis, the possibility of using multiple bacteriocins to overcome resistant strains may not be entirely feasible. Like other antibiotics, bacteriocins need to be used with caution in order to minimize the spread of resistance phenotypes.

At the present, scarce "in vivo" studies had been focused on characterize the side effects of the bacteriocins. The short proteasesmediated half life of bacteriocins, which imply its fast degradation, thought the possibility that bacteriocins may have lesser side effects than conventional antibiotics.

\section{Conclusions}

Bacteriocins are a promising substitute for conventional antibiotics for several reasons. Its narrow spectrum towards restricted target specificity (peptides target-design) of some bacteriocins minimizes their impact on commensal microbiota and may decrease the threat of opportunistic pathogens. Furthermore, most bacteriocins are active at lower concentrations, and their degradation products are easily metabolized by the body whith probably, lesser side effects compared with conventional antibiotics. With the development of resistance to many important antibiotics, another tool for fighting bacteria is invaluable.

Much of the research on bacteriocins has focused on their application for food preservation. Bacteriocins are active against several important human pathogens. Perhaps most promising is their activity against the foodborne pathogen Listeria monocytogenes, the deadliest bacterial source of food poisoning. Up to $30 \%$ of foodborne infections by L. monocytogenes in high-risk individuals are fatal. Other bacterial foodborne pathogens inhibited by some bacteriocins include Bacillus cereus, Clostridium botulinum, and C. perfringens. Beyond foodborne pathogens, bacteriocins are also active against other human pathogens, such as vancomycin-resistant enterococci and the opportunistic pathogen Staphylococcus aureus. Bacteriocins also show other potentially therapeutic properties as antineoplastic and antiviral agents. Although relatively little has been published on the use of bacteriocins in vivo to control bacterial infection, what is known is promising. Preliminary experiments have shown that some of these bacteriocins are effective in fighting infection by L. monocytogenes in mouse models. Now more is known about the mode of action of bacteriocins, and bacteriocins attempts engineering more power and stability have been successful. The application of bacteriocins as therapeutic agents is a rapidly developing area, and much remains to investigate.

\section{References}

1. Hellinger WC (2000) Confronting the problem of increasing antibiotic resistance. South Med J 93: 842-848.

2. Sparo M, Urbizu L, Solana MV, Pourcel G, Delpech G, et al. (2012) High-leve resistance to gentamicin: genetic transfer between Enterococcus faecalis isolated from food of animal origin and human microbiota. Lett Appl Microbiol 54: 119-125.

3. Cammue BPA, De Bolle MFC, Schoffs HME, Terras FRG, Thevissen K, et al (1994) Gene encoded antimicrobial peptides from plants. (eds) Antimicrobial peptides. Wiley, NewYork, 91-106.

4. Sahl HG (1994) Gene-encoded antibiotics made in bacteria. (eds) Antimicrobia peptides. Wiley, New York, 27-53.

5. Boman HG (1995) Peptide antibiotics and their role in innate immunity. Annu Rev Immunol 13: 61-92.

6. Charlet M, Chernysh S, Philippe H, Hetru C, Hoffmann JA, et al. (1996) Innate immunity. Isolation of several cysteine-rich antimicrobial peptides from the blood of a mollusc, Mytilus edulis. J Biol Chem 271: 21808-21813.

7. Nissen-Meyer J and Nes IF (1997) Ribosomally synthesized antimicrobia peptides: their function, structure, biogenesis and mechanism of action. Arch Microbiol 167: 67-77.

8. García-Olmedo F, Molina A, Alamillo JM, Rodríguez-Palenzuéla P (1998) Plant defense peptides. Biopolymers 47: 479-491.

9. Epand RM, Vogel HJ (1999) Diversity of antimicrobial peptides and their mechanisms of action. Biochim Biophys Acta 1462: 11-28.

10. Leippe M (1999) Antimicrobial and cytolytic polypeptides of amoeboid protozoa-effector molecules of primitive phagocytes. Dev Comp Immunol 23: 267-279.

11. Nes IF, Holo H, Fimland G, Hauge HH, Nissen-Meyer J (2002) Unmodified peptide bacteriocins produced by lactic acid bacteria. eds. Peptide Antibiotics: Discovery, Mode of Actions, and Applications. New York: Marcel Dekker, 81 117.

12. Pag U and Sahl HG (2002) Lanthionine-containing bacterial peptides. eds. 
Peptide Antibiotics: Discovery, Mode of Actions, and Applications. New York: Marcel Dekker, 47-80.

13. Zasloff M (2002) Antimicrobial peptides of multicellular organisms. Nature 415 389-395.

14. Ganz T (2003) Defensins: antimicrobial peptides of innate immunity. Nat Rev Immunol 3: 710-720.

15. Papagianni M (2003) Ribosomally synthesized peptides with antimicrobial properties: biosynthesis, structure, function, and applications. Biotechnol Adv 21: $465-499$

16. Bulet $P$, Stöcklin R, Menin L (2004) Anti-microbial peptides: from invertebrates to vertebrates. Immunol Rev 198: 169-184.

17. Brogden KA (2005) Antimicrobial peptides: pore formers or metabolic inhibitors in bacteria? Nat Rev Microbiol 3: 238-250

18. Gallo RL, Murakami M, Ohtake T, Zaiou M (2002) Biology and clinical relevance of naturally occurring antimicrobial peptides. J Allergy Clin Immunol 110: 823831.

19. Dennison SR, Wallace J, Harris F, Phoenix DA (2005a) Amphiphilic a-Helica Antimicrobial Peptides and Their Structure/Function Relationships. Prot Pept Letters 12: 27-29.

20. Maxwell AI, Morrison GM, Dorin JR (2003) Rapid sequence divergence in mammalian beta-defensins by adaptive evolution. Mol Immunol 40: 413-421.

21. Bachere E (2003) Anti-infectious immune effectors in marine invertebrates: Potential tools for disease control in larviculture. Aquaculture 227: 427-438.

22. Thomma BP, Cammue BP, Thevissen K (2003) Mode of action of plan defensins suggests therapeutic potential. Curr Drug Targets Infect Disord 3: $1-8$

23. Nes IF, Diep DB, Holo H (2007) Bacteriocin diversity in Streptococcus and Enterococcus. J Bacteriol 189: 1189-1198.

24. Hancock RE, Diamond G (2000) The role of cationic antimicrobial peptides in innate host defences. Trends Microbiol 8: 402-410.

25. Kamysz W, OkrÃ $\tilde{3}^{3 j} \mathrm{M}, \AA$ ukasiak J (2003) Novel properties of antimicrobial peptides. Acta Biochim Pol 50: 461-469.

26. Hancock RE (1997) Peptide antibiotics. Lancet 349: 418-422.

27. Hancock REW and Chapple DS (1999) Peptide antibiotics. Antimicrobial Agents and Chemotherapy 43: 317-323.

28. Dennison SR, Harris F, Phoenix DA (2005) Are oblique orientated alphahelices used by antimicrobial peptides for membrane invasion? Protein Pept Lett 12: 27-29.

29. Tagg JR, Dajani AS, Wannamaker LW (1976) Bacteriocins of gram-positive bacteria. Bacteriol Rev 40: 722-756.

30. Tagg JR (1992) Bacteriocins of Gram-positive bacteria: an opinión regarding their nature, nomenclature and numbers. Bacteriocins, microcins and lantibiotics. Nato Asi Series, H5. 65: 33-35.

31. Jack RW, Tagg JR, Ray B (1995) Bacteriocins of gram-positive bacteria Microbiol Rev 59: 171-200.

32. Diep DB, Nes IF (2002) Ribosomally synthesized antibacterial peptides in Gram positive bacteria. Curr Drug Targets 3: 107-122.

33. Line JE, Svetoch EA, Eruslanov BV, Perelygin VV, Mitsevich EV, et al (2008) Isolation and purification of enterocin E-760 with broad antimicrobial activity against gram-positive and gram-negative bacteria. Antimicrob Agents Chemother 52: 1094-1100.

34. Svetoch EA, Eruslanov BV, Perelygin VV, Mitsevich EV, Mitsevich IP, et al. (2008) Diverse antimicrobial killing by Enterococcus faecium E 50-52 bacteriocin. J Agric Food Chem 56: 1942-1948.

35. Reddy KV, Aranha C, Gupta SM, Yedery RD (2004) Evaluation of antimicrobia peptide nisin as a safe vaginal contraceptive agent in rabbits: in vitro and in vivo studies. Reproduction 128: 117-126.

36. Higazi AA, Ganz T, Kariko K, Cines DB (1996) Defensin modulates tissue-type plasminogen activator and plasminogen binding to fibrin and endothelial cells J Biol Chem 271: 17650-17655.

37. Cleveland J, Montville TJ, Nes IF, Chikindas ML (2001) Bacteriocins: safe, natural antimicrobials for food preservation. Int J Food Microbiol 71: 1-20.
38. Gillor O, Etzion A, Riley MA (2008) The dual role of bacteriocins as anti- and probiotics. Appl Microbiol Biotechnol 81: 591-606.

39. Gálvez A (1987) Purificación, caracterización y actividad biológica de una sustancia antibacteriana de amplio espectro producida por Streptococcus faecalis subsp. liquefaciens S-48. Tesis Doctoral. Universidad de Granada.

40. Riley MA, Gordon DM (1992) A survey of Col plasmids in natural isolates of Escherichia coli and an investigation into the stability of Col-plasmid lineages. J Gen Microbiol 138: 1345-1352.

41. Maqueda M, Gálvez A, Martínez-Bueno M, Valdivia E (1998) Widespread production of AS-48-like bacteriocins in strains of Enterococcus faecalis? Mo Microbiol 29: 1318-1319.

42. Gordon DM, Oliver E, Littlefield-Wyer J (2007) The diversity of bacteriocins in Gram-negative bacteria. Bacteriocins: ecology and evolution. Springer; Berlin 5-18.

43. Heng NCK, Wescombe PA, Burton JP, Jack RW, Tagg JR (2007) The diversity of bacteriocins in Gram-positive bacteria. Bacteriocins: ecology and evolution. Springer; Berlin 45-92.

44. Gratia J (1925) Sur un remarquable exemple d'antagonisme entre deux souches de colibacille. Comp. Rend. Soc Biol 93: 1040-1041.

45. Asensio C, Pérez-Díaz JC (1976) A new family of low molecular weight antibiotics from enterobacteria. Biochem Biophys Res Commun 69: 7-14.

46. Konisky J (1982) Colicins and other bacteriocins with established modes of action. Annu Rev Microbiol 36: 125-144.

47. Baquero F and Moreno F (1984) The microcins. FEMS Microbiol Lett 23: 117 124

48. Fath MJ, Zhang LH, Rush J, Kolter R (1994) Purification and characterization of colicin $\mathrm{V}$ from Escherichia coli culture supernatants. Biochemistry 33: 6911 6917

49. Riley MA, Wertz JE (2002) Bacteriocins: evolution, ecology, and application Annu Rev Microbiol 56: 117-137.

50. Drider D, Fimland G, Héchard Y, McMullen LM, Prévost $H$ (2006) The continuing story of class lla bacteriocins. Microbiol Mol Biol Rev 70: 564-582.

51. Eijsink VG, Axelsson L, Diep DB, Håvarstein LS, Holo H, et al. (2002) Production of class II bacteriocins by lactic acid bacteria; an example of biological warfare and communication. Antonie Van Leeuwenhoek 81: 639-654.

52. Maqueda M, Sánchez-Hidalgo M, Fernández M, Montalbán-López M, Valdivia E, et al. (2008) Genetic features of circular bacteriocins produced by Grampositive bacteria. FEMS Microbiol Rev 32: 2-22.

53. Nes IF, Diep DB, Håvarstein LS, Brurberg MB, Eijsink V, et al. (1996) Biosynthesis of bacteriocins in lactic acid bacteria. Antonie Van Leeuwenhoek 70: 113-128.

54. Klaenhammer TR (1993) Genetics of bacteriocins produced by lactic acid bacteria. FEMS Microbiol Rev 12: 39-85.

55. Franz CM, Holzapfel WH, Stiles ME (1999) Enterococci at the crossroads of food safety? Int J Food Microbiol 47: 1-24.

56. van Belkum MJ, Stiles ME (2000) Nonlantibiotic antibacterial peptides from lactic acid bacteria. Nat Prod Rep 17: 323-335

57. Ross RP, Morgan S, Hill C (2002) Preservation and fermentation: past, presen and future. Int J Food Microbiol 79: 3-16.

58. Cotter PD, Hill C, Ross RP (2005) Bacteriocins: developing innate immunity for food. Nat Rev Microbiol 3: 777-788

59. Sahl HG, Bierbaum G (1998) Lantibiotics: biosynthesis and biological activities of uniquely modified peptides from gram-positive bacteria. Annu Rev Microbio 52: $41-79$

60. Guder A, Wiedemann I, Sahl HG (2000) Posttranslationally modified bacteriocins--the lantibiotics. Biopolymers 55: 62-73.

61. van Belkum MJ, Hayema BJ, Geis A, Kok J, Venema G (1989) Cloning of two bacteriocin genes from a lactococcal bacteriocin plasmid. Appl Environ Microbiol 55: 1187-1191.

62. Schüller F, Benz R, Sahl HG (1989) The peptide antibiotic subtilin acts by formation of voltage-dependent multi-state pores in bacterial and artificial membranes. Eur J Biochem 182: 181-186. 
63. Gross E, Morell JL (1971) The structure of nisin. J Am Chem Soc 93: 46344635.

64. Wiedemann I, Breukink E, van Kraaij C, Kuipers OP, Bierbaum G, et al. (2001) Specific binding of nisin to the peptidoglycan precursor lipid II combines pore formation and inhibition of cell wall biosynthesis for potent antibiotic activity. J Biol Chem 276: 1772-1779.

65. Brötz H, Bierbaum G, Markus A, Molitor E, Sahl HG (1995) Mode of action of the lantibiotic mersacidin: inhibition of peptidoglycan biosynthesis via a novel mechanism? Antimicrob Agents Chemother 39: 714-719.

66. Ryan MP, Meaney WJ, Ross RP, Hill C (1998) Evaluation of lacticin 3147 and a teat seal containing this bacteriocin for inhibition of mastitis pathogens. Appl Environ Microbiol 64: 2287-2290.

67. Wiedemann I, Böttiger T, Bonelli RR, Schneider T, Sahl HG, et al. (2006) Lipid II-based antimicrobial activity of the lantibiotic plantaricin C. Appl Environ Microbiol 72: 2809-2814.

68. Martin NI, Sprules T, Carpenter MR, Cotter PD, Hill C, et al. (2004) Structural characterization of lacticin 3147, a two-peptide lantibiotic with synergistic activity. Biochemistry 43: 3049-3056.

69. Klaenhammer TR (1988) Bacteriocins of lactic acid bacteria. Biochimie 70: 337-349.

70. Lohans CT, Vederas JC (2012) Development of Class Ila Bacteriocins as Therapeutic Agents. Int J Microbiol 2012: 386410.

71. Bruno ME, Montville TJ (1993) Common mechanistic action of bacteriocins from lactic Acid bacteria. Appl Environ Microbiol 59: 3003-3010.

72. Upreti GC, Hinsdill RD (1975) Production and mode of action of lactocin 27: bacteriocin from a homofermentative Lactobacillus. Antimicrob Agents Chemother 7: 139-145.

73. Park SH, Itoh K, Fujisawa T (2003) Characteristics and identification of enterocins produced by Enterococcus faecium JCM 5804T. J Appl Microbiol 95: 294-300

74. De Vuyst L, Foulquié Moreno MR, Revets H (2003) Screening for enterocins and detection of hemolysin and vancomycin resistance in enterococci of different origins. Int J Food Microbiol 84: 299-318.

75. Foulquié Moreno MR, Sarantinopoulos P, Tsakalidou E, De Vuyst L (2006) The role and application of enterococci in food and health. Int J Food Microbiol 106: 1-24.

76. Kemperman R, Kuipers A, Karsens H, Nauta A, Kuipers O, et al. (2003) Identification and characterization of two novel clostridial bacteriocins, circularin A and closticin 574. Appl Environ Microbiol 69: 1589-1597.

77. Maqueda M, Gálvez A, Bueno MM, Sanchez-Barrena MJ, González C, et al. (2004) Peptide AS-48: prototype of a new class of cyclic bacteriocins. Curr Protein Pept Sci 5: 399-416.

78. Giraffa G (1995) Enterococcal bacteriocins: their potential use as anti Listeria factors in dairy technology. Food Microbiol 12: 291-299.

79. Foulquié Moreno MR, Callewaert R, Devreese B, Van Beeumen J, De Vuyst $L$ (2003) Isolation and biochemical characterisation of enterocins produced by enterococci from different sources. J Appl Microbiol 94: 214-229.

80. Sparo M, Nuñez GG, Castro M, Calcagno ML, García Allende MA, et al. (2008) Characteristics of an environmental strain, Enterococcus faecalis CECT7121, and its effects as additive on craft dry-fermented sausages. Food Microbiol 25: 607-615

81. Sparo MD, Jones DG, Sánchez Bruni SF (2009) In vitro efficacy of the novel peptide CECT7121 against bacteria isolated from mastitic dairy cattle. Lett Appl Microbiol 48: 187-192.

82. Sparo MD, Jones DG, Sánchez Bruni SF (2009) Assessment of the in vitro efficacy of the novel antimicrobial peptide CECT7121 against human Grampositive bacteria from serious infections refractory to treatment. Chemotherapy 55: 270-277.

83. Basualdo J, Sparo M, Chiodo P, Ciarmela M, Minvielle M (2007) Oral treatment with a potential probiotic (Enterococcus faecalis CECT 7121) appears to reduce the parasite burden of mice infected with Toxocara canis. Ann Trop Med Parasitol 101: 559-562.

84. Castro M, Sparo MD, Molina M, Andino J, Manghi M (2008a) Enterococcus faecalis CECT7121 induces systemic immunomodulatory effects and protects from Salmonella infection. Int J Prob Preb 2: 215-224.
85. Castro M, Molina M, Sparo M, Manghi M (2008b) Effects of Enterococcus faecalis CECT7121 on the specific immune response after dtpw vaccination. Int J Prob Preb. 3: 25-30.

86. Di Sciullo P, Castro M, Molina M, Sparo M, Mongini C, Manghi M (2006) Efecto Antiproliferativo De Enterococcus faecalis CECT7121 Sobre Células Del Linfoma T MURINO LBC. LIV Reunión Anual Sociedad Argentina de Inmunología, LI Reunión Sociedad Argentina de Investigación Clínica. Mar del Plata, 8 y el 11 de noviembre de 2006.

87. Héchard Y, Sahl HG (2002) Mode of action of modified and unmodified bacteriocins from Gram-positive bacteria. Biochimie 84: 545-557.

88. Balla E, Dicks LM, Du Toit M, Van Der Merwe MJ, Holzapfel WH (2000) Characterization and cloning of the genes encoding enterocin $1071 \mathrm{~A}$ and enterocin 1071B, two antimicrobial peptides produced by Enterococcus faecalis BFE 1071. Appl Environ Microbiol 66: 1298-1304.

89. Zhu WM, Liu W, Wu DQ (2000) Isolation and characterization of a new bacteriocin from Lactobacillus gasseri KT7. J Appl Microbiol 88: 877-886.

90. Foulquié Moreno MR, Rea MC, Cogan TM, De Vuyst L (2003) Applicability of a bacteriocin-producing Enterococcus faecium as a co-culture in Cheddar cheese manufacture. Int J Food Microbiol 81: 73-84.

91. Kato T, Matsuda T, Yoneyama Y, Kato H, Nakamura R (1993) Isolation of Enterococcus faecium with antibacterial activity and characterization of its bacteriocin. Biosci Biotechnol Biochem 57: 551-556.

92. Mendoza F, Maqueda M, Gálvez A, Martínez-Bueno M, Valdivia E (1999) Antilisterial activity of peptide AS-48 and study of changes induced in the cel envelope properties of an AS-48-adapted strain of Listeria monocytogenes. Appl Environ Microbiol 65: 618-625

93. Ross RP, Galvin M, McAuliffe O, Morgan SM, Ryan MP, et al. (1999) Developing applications for lactococcal bacteriocins. Antonie Van Leeuwenhoek 76: 337346.

94. Chung KT, Dickson JS, Crouse JD (1989) Effects of nisin on growth of bacteria attached to meat. Appl Environ Microbiol 55: 1329-1333.

95. Ennahar S, Sashihara T, Sonomoto K, Ishizaki A (2000) Class Ila bacteriocins: biosynthesis, structure and activity. FEMS Microbiol Rev 24: 85-106.

96. Raloff J (1998) Staging germ warfare in foods. Sci News 153: 89-90.

97. Mkrtchyan H, Gibbons S, Heidelberger S, Zloh M, Limaki HK (2010) Purification, characterisation and identification of acidocin LCHV, an antimicrobial peptide produced by Lactobacillus acidophilus n.v. Er 317/402 strain Narine. Int J Antimicrob Agents 35: 255-260.

98. Gálvez A, Abriouel H, López RL, Ben Omar N (2007) Bacteriocin-based strategies for food biopreservation. Int J Food Microbiol 120: 51-70.

99. Chen H and Hoover DG (2003) Bacteriocins and their food aplications. Comp Rev Food Sci Food Saf 2: 82-100.

100.Dykes GA, Hastings JW (1998) Fitness costs associated with class Ila bacteriocin resistance in Listeria monocytogenes B73. Lett Appl Microbiol 26 $5-8$.

101. Bouttefroy A and Milliere $J(2000)$ Nisin-curvaticin 13 combinations for avoiding the regrowth of bacteriocin resistant cells of bacteriocin resistan cells of Listeria monocytogenes ATCC 15313. Int J Food Microbiol 62: 65-75.

102. Vignolo G, Palacios J, Farías ME, Sesma F, Schillinger U, et al. (2000) Combined effect of bacteriocins on the survival of various Listeria species in broth and meat system. Curr Microbiol 41: 410-416.

103. Rekhif N, Atrih A, Lefebvre G (1994) Selection and properties of spontaneous mutants of Listeria monocytogenes ATCC 15313 resistant to different bacteriocins produced by lactic acid bacteria strains. Current Microbiol 28 237-241.

104. Dabour N, Zihler A, Kheadr E, Lacroix C, Fliss I (2009) In vivo study on the effectiveness of pediocin PA-1 and Pediococcus acidilactici UL5 at inhibiting Listeria monocytogenes. Int J Food Microbiol 133: 225-233.

105. Kheadr E, Bernoussi N, Lacroix C, Fliss I. (2004) "Comparison of the sensitivity of commercial strains and infant isolates of bifidobacteria to antibiotics and bacteriocins" Int Dairy J 14: 1041-1053.

106. Le Blay G, Lacroix C, Zihler A, Fliss I (2007) In vitro inhibition activity of nisin A, nisin Z, pediocin PA-1 and antibiotics against common intestinal bacteria. Lett Appl Microbiol 45: 252-257. 
107. Bernbom N, Jelle B, Brogren CH, Vogensen FK, Nørrung B, et al. (2009) Pediocin PA-1 and a pediocin producing Lactobacillus plantarum strain do not change the HMA rat microbiota. Int J Food Microbiol 130: 251-257.

108. Ingham A, Ford M, Moore RJ, Tizard M (2003) The bacteriocin piscicolin 126 retains antilisterial activity in vivo. J Antimicrob Chemother 51: 1365-1371.

109. Rihakova J, Cappelier JM, Hue I, Demnerova K, Fédérighi M, et al. (2010) In vivo activities of recombinant divercin V41 and its structural variants against Listeria monocytogenes. Antimicrob Agents Chemother 54: 563-564.

110. Ramaswamy V, Cresence VM, Rejitha JS, Lekshmi MU, Dharsana KS, et al. (2007) Listeria--review of epidemiology and pathogenesis. J Microbiol Immunol Infect 40: 4-13.

111. Bhunia AK, Johnson MC, Ray B, Belden EL (1990) Antigenic property of pediocin $\mathrm{AcH}$ produced by Pediococcus acidilactici $\mathrm{H}$. J Appl Bacteriol 69 211-215.

112. Bhunia AK, Johnson MC, Ray B (1988) Purification, characterization and antimicrobial spectrum of a bacteriocin produced by Pediococcus acidilactici. J Appl Bacteriol 65: 261-268.

113. Kheadr E, Zihler A, Dabour N, Lacroix C, Le Blay G, et al. (2010) Study of the physicochemical and biological stability of pediocin PA-1 in the upper gastrointestinal tract conditions using a dynamic in vitro model. J Appl Microbiol 109: 54-64.

114. Benech RO, Kheadr EE, Laridi R, Lacroix C, Fliss I (2002) Inhibition of Listeria innocua in cheddar cheese by addition of nisin Z in liposomes or by in situ production in mixed culture. Appl Environ Microbiol 68: 3683-3690.

115. Were LM, Bruce B, Davidson PM, Weiss J (2004) Encapsulation of nisin and lysozyme in liposomes enhances efficacy against Listeria monocytogenes. J Food Prot 67: 922-927.

116. Sass P, Jansen A, Szekat C, Sass V, Sahl HG, et al. (2008) The lantibiotic mersacidin is a strong inducer of the cell wall stress response of Staphylococcus aureus. BMC Microbiol 8: 186.

117. Kruszewska D, Sahl HG, Bierbaum G, Pag U, Hynes SO, et al. (2004) Mersacidin eradicates methicillin-resistant Staphylococcus aureus (MRSA) in a mouse rhinitis model. J Antimicrob Chemother 54: 648-653.

118. Chatterjee S, Chatterjee DK, Jani RH, Blumbach J, Ganguli BN, et al. (1992) Mersacidin, a new antibiotic from Bacillus. In vitro and in vivo antibacterial activity. J Antibiot (Tokyo) 45: 839-845.

119. Limbert M, Isert D, Klesel N, Markus A, Seibert G, et al. (1991) Chemotherapeutic properties of mersacidin in vitro and in vivo. (eds) Nisin and novel lantibiotics. ESCOM, Leiden, The Netherlands.

120. Galvin M, Hill C, Ross RP (1999) Lacticin 3147 displays activity in buffer against gram-positive bacterial pathogens which appear insensitive in standard plate assays. Lett Appl Microbiol 28: 355-358.

121.Jung G (1991a) Lantibiotics-ribosomally synthesized biologically active polypeptides containing sulfide bridges and a, B-didehydroamino acids. Angew Chem Int Ed Engl 30: 1051-1068.

122. Jung G (1991b) Lantibiotics: a survey. In: Jung G, Sahl HG (eds) Nisin and novel lantibiotics. ESCOM Science Publishers, Leiden, The Netherlands, 1-34.

123. Kellner R, Jung G, Hörner T, Zähner H, Schnell N, et al. (1988) Gallidermin: a new lanthionine-containing polypeptide antibiotic. Eur J Biochem 177: 53-59.

124. Niu WW, Neu HC (1991) Activity of mersacidin, a novel peptide, compared with that of vancomycin, teicoplanin, and daptomycin. Antimicrob Agents Chemother 35: 998-1000.

125. Bonelli R, Wiedemann RI, Sahl HG (2006) Lantibiotics. In: Kastin A (ed) Handbook of biologically active peptides. Elsevier, New York, NY.

126.van Kraaij C, de Vos WM, Siezen RJ, Kuipers OP (1999) Lantibiotics: biosynthesis, mode of action and applications. Nat Prod Rep 16: 575-587.

127. Tagg JR (2004) Prevention of streptococcal pharyngitis by anti-Streptococcus pyogenes bacteriocin-like inhibitory substances (BLIS) produced by Streptococcus salivarius. Indian J Med Res 119 Suppl: 13-16.

128. Hillman JD, Novák J, Sagura E, Gutierrez JA, Brooks TA, et al. (1998) Genetic and biochemical analysis of mutacin 1140, a lantibiotic from Streptococcus mutans. Infect Immun 66: 2743-2749.

129. Bower CK, McGuire J, Daeschel MA (1995) Suppression of Listeria monocytogenes colonization following adsorption of nisin onto silica surfaces Appl Environ Microbiol 61: 992-997.

130. Bower CK, Parker JE, Higgins AZ, Oest ME, Wilson JT, et al. (2002) Protein antimicrobial barriers to bacterial adhesion: in vitro and in vivo evaluation of nisin-treated implantable materials. Surf B: Biointerfaces 25: 81-90.

131. Goldstein BP, Wei J, Greenberg K, Novick R (1998) Activity of nisin against Streptococcus pneumoniae, in vitro, and in a mouse infection model. J Antimicrob Chemother 42: 277-278.

132. Giacometti A, Cirioni O, Barchiesi F, Fortuna M, Scalise G (1999) In-vitro activity of cationic peptides alone and in combination with clinically used antimicrobial agents against Pseudomonas aeruginosa. J Antimicrob Chemother 44: 641-645.

133. Knoetze H, Todorov SD, Dicks LM (2008) A class Ila peptide from Enterococcus mundtii inhibits bacteria associated with otitis media. Int J Antimicrob Agents 31: $228-234$.

134. Sosunov V, Mischenko V, Eruslanov B, Svetoch E, Shakina Y, et al. (2007) Antimycobacterial activity of bacteriocins and their complexes with liposomes. J Antimicrob Chemother 59: 919-925.

135. De Kwaadsteniet M, Doeschate KT, Dicks LM (2009) Nisin F in the treatment of respiratory tract infections caused by Staphylococcus aureus. Lett Appl Microbiol 48: 65-70.

136. Naghmouchi K, Drider D, Kheadr E, Lacroix C, Prévost H, et al. (2006) Multiple characterizations of Listeria monocytogenes sensitive and insensitive variants to divergicin M35, a new pediocin-like bacteriocin. J Appl Microbiol 100: 29-39.

137. Naghmouchi K, Kheadr E, Lacroix C, Fliss I (2007) Class I/Class Ila bacteriocin cross-resistance phenomenon in Listeria monocytogenes. Food Microbiol 24 718-727.

138. Corr SC, Li Y, Riedel CU, O'Toole PW, Hill C, et al. (2007) Bacteriocin production as a mechanism for the antiinfective activity of Lactobacillus salivarius UCC118. Proc Natl Acad Sci U S A 104: 7617-7621.

139. Delves-Broughton J, Blackburn P, Evans RJ, Hugenholtz J (1996) Applications of the bacteriocin, nisin. Antonie Van Leeuwenhoek 69: 193-202.

140. de Carvalho AA, Mantovani HC, Vanetti MC (2007) Bactericidal effect of bovicin $\mathrm{HC} 5$ and nisin against Clostridium tyrobutyricum isolated from spoiled mango pulp. Lett Appl Microbiol 45: 68-74.

141. Bartoloni A, Mantella A, Goldstein BP, Dei R, Benedetti M, et al. (2004) In-vitro activity of nisin against clinical isolates of Clostridium difficile. $\mathrm{J}$ Chemother 16: 119-121.

142. Abriouel H, Valdivia E, Gálvez A, Maqueda M (1998) Response of Salmonella choleraesuis LT2 spheroplasts and permeabilized cells to the bacteriocin AS48. Appl Environ Microbiol 64: 4623-4626.

143. Jennes W, Dicks LM, Verwoerd DJ (2000) Enterocin 012, a bacteriocin produced by Enterococcus gallinarum isolated from the intestinal tract of ostrich. J Appl Microbiol 88: 349-357.

144. Kim TS, Hur JW, Yu MA, Cheigh Cl, Kim KN, et al. (2003) Antagonism of Helicobacter pylori by bacteriocins of lactic acid bacteria. J Food Prot 66: 3-12.

145. Fredenhagen A, Fendrich G, Märki F, Märki W, Gruner J, et al. (1990) Duramycins $\mathrm{B}$ and $\mathrm{C}$, two new lanthionine containing antibiotics as inhibitors of phospholipase A2. Structural revision of duramycin and cinnamycin. J Antibiot (Tokyo) 43: 1403-1412.

146. Märki F, Hänni E, Fredenhagen A, van Oostrum J (1991) Mode of action of the lanthionine-containing peptide antibiotics duramycin, duramycin $\mathrm{B}$ and $\mathrm{C}$, and cinnamycin as indirect inhibitors of phospholipase A2. Biochem Pharmacol 42: $2027-2035$

147. Shiba T, Wakamiya T, Fukase K, Ueki Y, Teshima T, Nishikawa M (1991) Structure of the lanthionine peptides nisin, ancovenin and lanthiopeptin. (eds) Nisin and novel lantibiotics. Escom, Leiden, The Netherlands.

148. Kido Y, Hamakado T, Yoshida T, Anno M, Motoki Y, et al. (1983) Isolation and characterization of ancovenin, a new inhibitor of angiotensin I converting enzyme, produced by actinomycetes. J Antibiot (Tokyo) 36: 1295-1299.

149.Babasaki K, Takao T, Shimonishi Y, Kurahashi K (1985) Subtilosin A, a new antibiotic peptide produced by Bacillus subtilis 168: isolation, structura analysis, and biogenesis. J Biochem 98: 585-603

150.Sutyak KE, Wirawan RE, Aroutcheva AA, Chikindas ML (2008) Isolation of the 
Citation: Urbizu L, Sparo M, Sánchez Bruni S (2013) Bacterial Antagonist Mediated Protein Molecules. Clin Exp Pharmacol 3: 123. doi:10.4172/21611459.1000123

Bacillus subtilis antimicrobial peptide subtilosin from the dairy product-derived Bacillus amyloliquefaciens. J Appl Microbiol 104: 1067-1074.

151. Aranha C, Gupta S, Reddy KV (2004) Contraceptive efficacy of antimicrobia peptide Nisin: in vitro and in vivo studies. Contraception 69: 333-338.

152. Sutyak KE, Anderson RA, Dover SE, Feathergill KA, Aroutcheva AA, et al (2008) Spermicidal activity of the safe natural antimicrobial peptide subtilosin. Infect Dis Obstet Gynecol 2008: 540758.

153. Silkin L, Hamza S, Kaufman S, Cobb SL, Vederas JC (2008) Spermicidal bacteriocins: lacticin 3147 and subtilosin A. Bioorg Med Chem Lett 18: 31033106.

154. Taylor I, Hirsh A, Mattick TR (1949) The treatment of bovine streptococcal and staphylococcal mastitis with nisin. The Vet Record 61: 197-198.

155. Broadbent JR, Chou YC, Gillies K, Kondo JK (1989) Nisin inhibits several gram-positive, mastitis-causing pathogens. J Dairy Sci 72: 3342-3345.

156. Ryan MP, Flynn J, Hill C, Ross RP, Meaney WJ (1999) The natural food grade inhibitor, lacticin 3147, reduced the incidence of mastitis after experimental challenge with Streptococcus dysgalactiae in nonlactating dairy cows. J Dairy Sci 82: 2625-2631.

157. Xie J, Zhang R, Shang C, Guo Y (2009) Isolation and characterization of a bacteriocin produced by an isolated Bacillus subtilis LFB112 that exhibits antimicrobial activity against domestic animal pathogens. Afr J Biotechnol 8: 5611-5619.
158. Pieterse R, Todorov SD, Dicks LM (2008) Bacteriocin ST91KM, produced by Streptococcus gallolyticus subsp. macedonicus ST91KM, is a narrowspectrum peptide active against bacteria associated with mastitis in dairy cattle. Can J Microbiol 54: 525-531.

159. Pieterse R, Todorov S, Dicks LMT (2010) Mode of action and in vitro susceptibility of mastitis pathogens to macedocin ST91KM and preparation of a teat seal containing the bacteriocins. Braz J Microbiol 41: 133-145.

160. Chiodo PG, Sparo MD, Pezzani BC, Minvielle MC, Basualdo JA (2010) In vitro and in vivo effects of Enterococcus faecalis CECT7121 on Toxocara canis. Mem Inst Oswaldo Cruz 105: 615-620.

161. Murinda SE, Rashid KA, Roberts RF (2003) In vitro assessment of the cytotoxicity of nisin, pediocin, and selected colicins on simian virus 40-transfected human colon and Vero monkey kidney cells with trypan blue staining viability assays. J Food Prot 66: 847-853.

162. Jasniewski J, Cailliez-Grimal C, Chevalot I, Millière JB, Revol-Junelles AM (2009) Interactions between two carnobacteriocins Cbn BM1 and Cbn B2 from Carnobacterium maltaromaticum CP5 on target bacteria and Caco-2 cells. Food Chem Toxicol 47: 893-897.

163. Kaur G, Malik RK, Mishra SK, Singh TP, Bhardwaj A, et al. (2011) Nisin and class Ila bacteriocin resistance among Listeria and other foodborne pathogens and spoilage bacteria. Microb Drug Resist 17: 197-205.

164. Crandall AD, Montville TJ (1998) Nisin resistance in Listeria monocytogenes ATCC 700302 is a complex phenotype. Appl Environ Microbiol 64: 231-237. 